\title{
追憶一日米セミナーに宮㟝さんを偲ぶ
}

\section{The Memory of Dr. Hiroshi MIYAZAKI in the United States- Japan Seminar on Analytical Biomedical Mass Spectrometry}

\author{
中田尚男 $1,2 *$ \\ Hisao NAKATA ${ }^{1,2 *}$ \\ 1 元日本質量分析学会会長 A One-time President of the MSSJ \\ 2 愛知教育大学名誉教授 Professor Emeritus of Aichi Kyoiku University
}

1975 年（昭和 50 年）は，わが国におけるマススペクトロメトリーの歴史にとってェポックメイキングな年であった. 一つは，立松 晃・宮㠃 浩・鈴木真言の 3 氏の共著による名著「医学と薬学のためのマススペクトロメトリー」が出版さ れたこと，そしてもう一つは，「日米セミナー」という，当時としては画期的な会議が開催されたことである，それと相前 後して私は宮㠃さんと知り合いとなったので，以後数十年にわたってたいへん親しくしていただいたことになる.

1975 年といえば, 「有機化合物のマススペクトロメトリー討論会」が発足からすでに 10 回目となっていたし，この年の ちょうど 1 年前, 現在の BMS コンファレンスの前身である「臨床マス談話会」あ始まり, Organic \& Biomedical Mass Spectrometry が全盛期を迎えようとする時代であった。 そんなある日, 名城大学薬学部の故立松 晃教授 (所属ならびに役 職名は当時の屯の, 以下同じ) から電話があり, 今度アメリカの研究者を何人か招いてセミナーをやりたいのだが手伝って くれないか，とのことであった．詳しく聞いてみると，日米双方から 10１5名程度のメンバーを選び，4〜5 日間どこか に泊まり込みでいろいろ議論したいのだという。あちろん喜んでお手伝いをお引き受けした。

セミナーのタイトルは United States-Japan Seminar on Analytical Biomedical Mass Spectrometry, 会場は箱根の ホテル小涌園と決まった。 日本側メンバーは，セミナーのタイトルからわかると抢り，主にバイオ関係で活発な研究をな さっておられる方々を中心としながらも, 物理化学系の土屋利一さんや土屋正彦先生, 量子化学の立場から有機分子のフ ラグメンテーションについて独特の考え方を展開しておられた広田鋼蔵先生など，その当時の鋝々たるメンバーであっ た. 米国側の人選については, 宮㠃さんや池川信夫先生がよく知っておられた E. C. Horning 先生に㧍任せし, 研究者であ あった奥様の M. G. Horning さんを含め 10 名のメンバーが選ばれた (Table 1). Horning 先生ご夫妻や, J. L. Franklin 教授, M. S. B. Munson 教授などの著名なベテラン研究者のほか, K. Biemann, J. A. McCloskey, D. M. Desiderio, C. C. Sweeley の各先生のような, 当時はまだ若手のバリバリの人たちが参加することになったわけである (写真 1). 有機系の F. W. McLafferty 教授が入っていないのが少し気になったが，たまたま来日のご都合がっかなかったのかもしれない，な お，以上の正式メンバーのほかに，20名ほどの方がオブザーバーとして参加者名簿に名を連ねている.

こうして，この日米セミナーは 1975 年（昭和 50 年）11月 16 日（日）の夕方から 20 日（木）まで，延べ 5 日間にわ たって繰り広げられたのである. 毎日, 午前・午後ともに熱い議論が行われた. プログラムの詳細やそれぞれの発表に対す

Table 1. アメリカ側の参加メンバー

\begin{tabular}{ll} 
J. L. Franklin & Rice University \\
E. C. Horning & Baylor College of Medicine \\
M. G. Horning & Baylor College of Medicine \\
K. Biemann & Massachusetts Institute of Technology \\
C. C. Sweeley & Michigan State University \\
J. A. McCloskey & University of Utah \\
P. Klein & Argonne National Laboratory \\
D. M. Desiderio & Baylor College of Medicine \\
M. S. B. Munson & University of Delaware \\
M. E. Wall & Research Triangle Institute \\
\hline
\end{tabular}

This paper is dedicated to the memory of Dr. Hiroshi Miyazaki.

*日本質量分析学会名誉会員

略語, BMS: biological mass spectrometry 


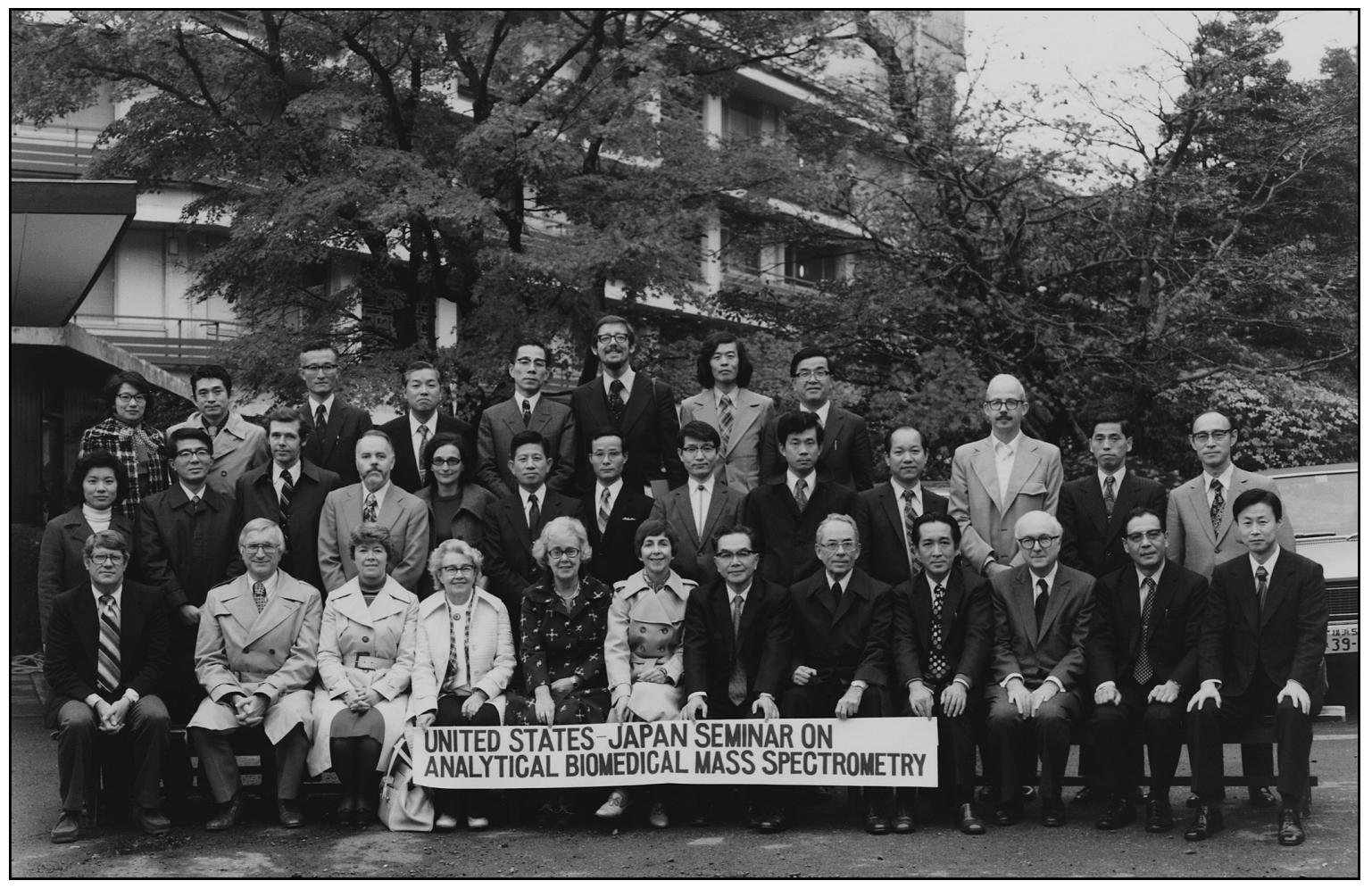

写真 1. セミナーのメンバー

後列, 向かって左から 5 人目が宮㠃さん。な撮前列には, アメリカ側責任者の J. L. Franklin と E. C. Horning をはじ めC. C. Sweeley，P. Klein，日本側の中心となられた土屋利一，立松 晃のほか鈴木真言，土屋正彦らが並んでいる. 中段 には上野民夫, K. Biemann, J. A. McCloskey, 南原利夫, 中川有造, 松本 勇, M. S. B. Munson, 馬場茂雄, 池川信夫 などのお顔が見える．後列は宮墒さんのほか丸山悠司，D. M. Desiderio など（以上いずれ屯敬称略）。 なお，後列左から 3 人目が筆者 (中田尚男).

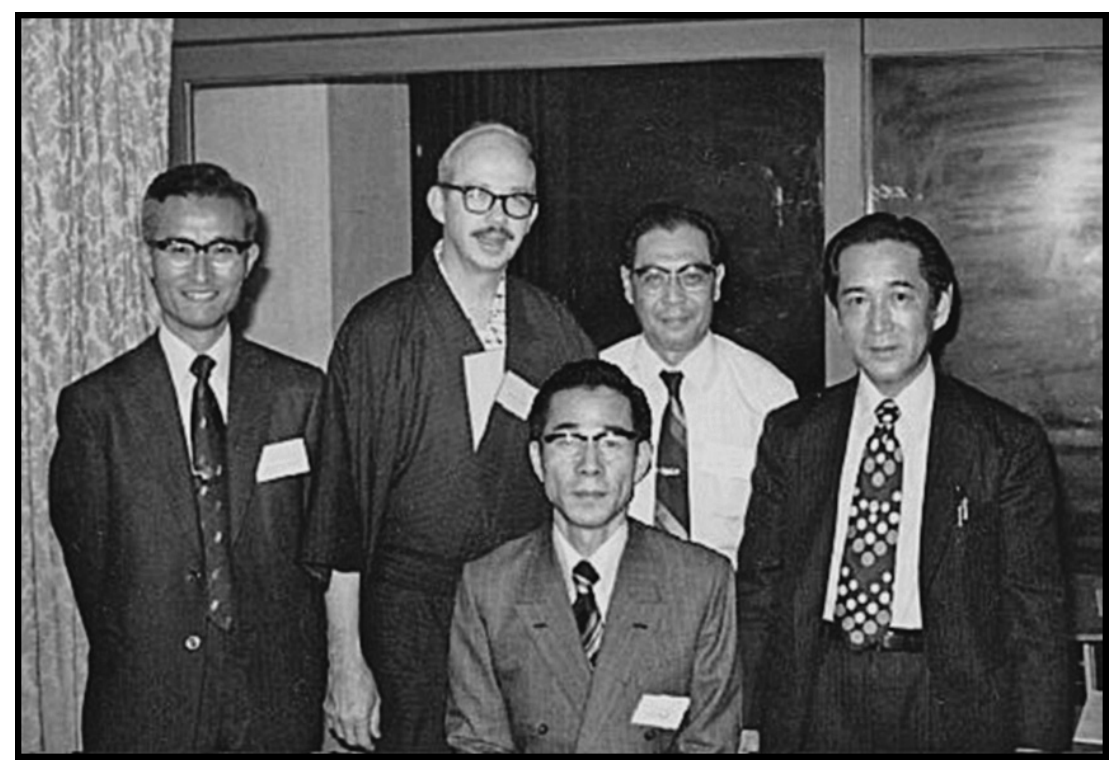

写真 2. 宮㠃さんを囲んで

腰掛けている宮㠃さんを中心に，左から筆者，M. S. B. Munson 先生，鈴木真 言さん，立松 晃先生.

る討論の内容については詳しく述べないが，参加メンバーが比較的少人数のため遠慮なしに本音で意見を言い合うことが でき，最終日には Round Table Discussion で全体の総括を行うなど，極めて有意義なセミナーであった.

毎日のセッションは毎朝 9 時から始まり夜まで続く。特に夜は自由時間で，各人が個人的に相手をつかまえて自分たち の仕事についての議論。そんな時，いつ屯中心になって大声で議論していたのが宮㠃さんであった（写真 2). 夜遅くまで の討論ではどうしてもアルコールが入るので，次の朝はなかなか起きられない．しかし米国のメンバーたちは元気いっぱ い。私など「扔一い，ナカ夕さん，バスへ行こう!」と，毎朝Desiderioさんに起こされる始末だった。 大浴場へ行ってみ 


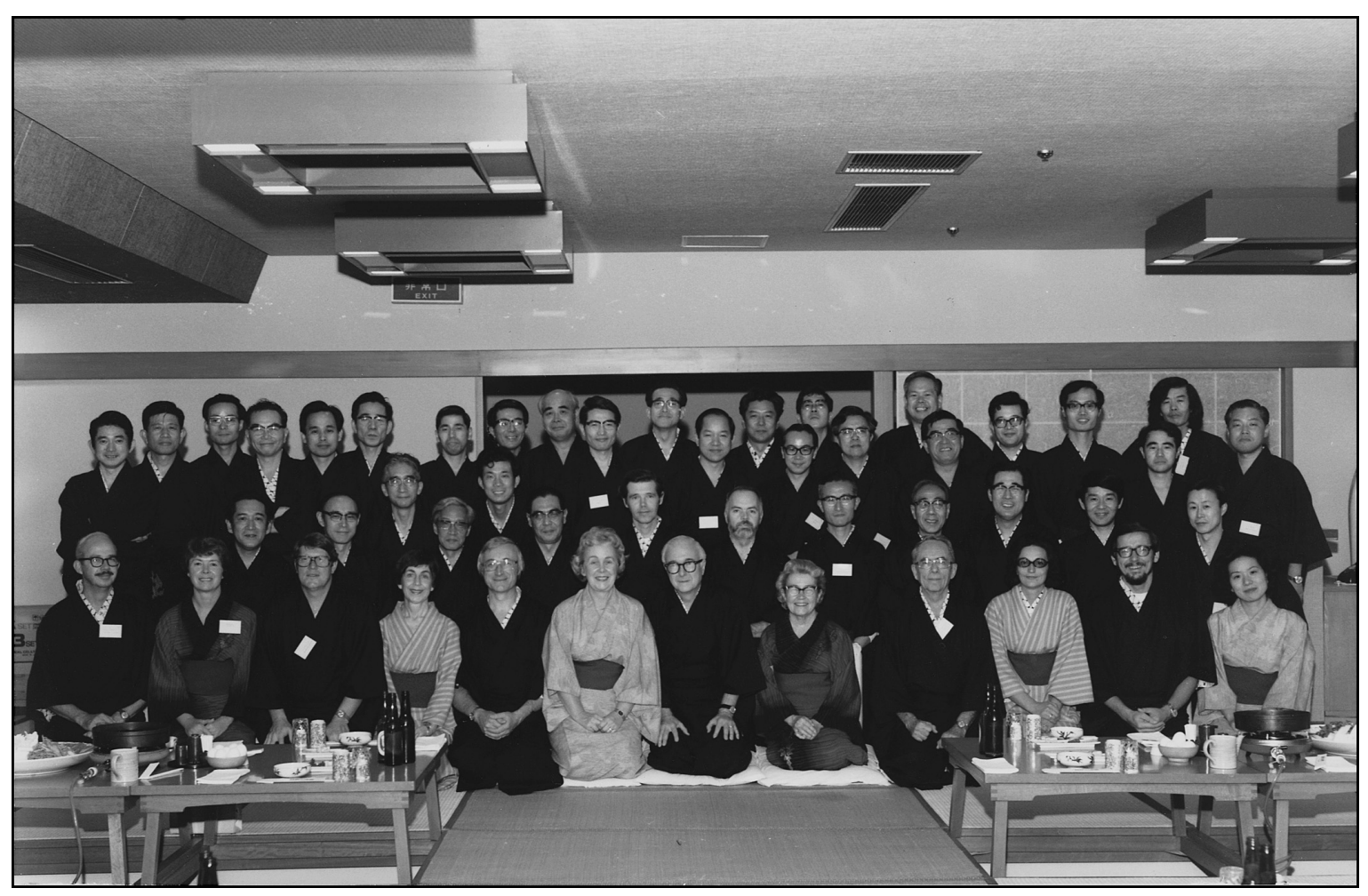

写真 3. Sayonara Banquet

全員ゆかたと着物での勢揃い, 最後列, 左から 6 人目が宮㠃さん.

ると立松先生や宮㠃さんが悠々と湯船につかっているということもしばしば。素っ裸で入る大浴場が外国人には珍しいの か，本当にみんな日本の風呂が気に入ったようだった。

夜のセッションは, 各自それぞれの議論が終わると, 第一夜が日本側主催のレセプション, 2 日目の夜が米国側主催の懇 親会であった。 そして最後の夜は Sayonara Banquetとして, 参加者全員が「ゆかた」や着物姿で大広間に集まっての大 宴会. 米国からの参加者たちは, ご婦人方も含めて思いのほかきっちりと「ゆかた」や着物を着こなし, 畳の部屋に座って の会席 (写真 3). 主なメンバーが一人ひとり簡単なスピーチを行うことになったが，セミナーの感想あり，コメントあり， ジョークありで, 賑やかな会となった。 シャンパン，ビール，お酒，焼酎，ワインと，血中アルコール濃度が高まるにつれ て会はしだいに盛り上がっていったが，なかでも圧巻だったのは，宮㠃さんなど薬学系の先生方が一列に連なって唄いな がら練り歩く「薬学踊り」. われわれのような生真面目?な理学部系の者にとっては，あっと驚くシロモノであった。 ほと んぞ全員が笑いこけ，そのユニークな仕草は外国人たちにも大受けした。 しかし歌詞の日本語が米国のご婦人方にはわか らなかったのが幸いであった。私にはとてあ通訳できない，

こうして，大成功を収めたこの 5 日間の日米セミナーは，ある意味でわが国のマススペクトロメトリーの歴史に拉ける 画期的な出来事であったと思う.

この日米セミナーのみならず，日本質量分析学会の総合討論会やBMS コンファレンスなどさまざまな学会で宮㠃さん に打会いするたびごとに，研究上の疑問点を互いに議論し合い，またマススペクトロメトリーの現状や将来などについて あ酒を飲みながら本音で語り合ったことが懐かしく思い出される。常々宮㠃さんは，「私はいろいろと混ざりものの多い試 料を何であ扱うヤクザみたいなあのだが， あんたは簡単な構造の純粋な化合物を測定しては理屈をこねるのだから二本差 しだよ权」と言って抢られた。 ヤクザに対する二本差しという意味はよくわからないが, 抄そらく応用的な研究と基礎的な 研究との間のギャップを皮肉って言われたあのと理解し, 常にその両者の関係を念頭におき, お互いの立場を尊重しなが ら議論したあのである。 いっあ決まって夜 8 時過ぎにかかってくる長いながい電話には, 構造式やフラグメンテーション の矢印を書くための紙と鉛筆を欠かすことができなかったが，今はあう，それあ想い出となってしまった．

宮㠃さんの鋭い洞察力に基づいた発言やその活動的な行動がわが国のマススペクトロメトリーのレベルアップに大きく 寄与したことは疑う余地あない. あの独特な話し方, あのよく透る低音の拈声を, あはや聞くことができないのは本当に残 念である.いつあいただいていた美しい毛筆のお手紙を大切にしながら, 心よりご冥福を㧍祈りしたい. 